Louisiana State University

LSU Digital Commons

Faculty Publications

School of Animal Sciences

$4-1-2008$

\title{
The Effect of Diets Varying in Dietary Cation-Anion Difference Fed in Late Gestation and in Lactation on Sow Productivity
}

\author{
M. L. Roux \\ LSU Agricultural Center \\ S. L. Johnston \\ LSU Agricultural Center \\ R. D. Lirette \\ LSU Agricultural Center \\ T. D. Bidner \\ LSU Agricultural Center \\ L. L. Southern \\ LSU Agricultural Center
}

See next page for additional authors

Follow this and additional works at: https://digitalcommons.Isu.edu/animalsciences_pubs

\section{Recommended Citation}

Roux, M., Johnston, S., Lirette, R., Bidner, T., Southern, L., \& Jardon, P. (2008). The Effect of Diets Varying in Dietary Cation-Anion Difference Fed in Late Gestation and in Lactation on Sow Productivity. Professional Animal Scientist, 24 (2), 149-155. https://doi.org/10.15232/S1080-7446(15)30829-9

This Article is brought to you for free and open access by the School of Animal Sciences at LSU Digital Commons. It has been accepted for inclusion in Faculty Publications by an authorized administrator of LSU Digital Commons.

For more information, please contact ir@lsu.edu. 


\section{Authors}

M. L. Roux, S. L. Johnston, R. D. Lirette, T. D. Bidner, L. L. Southern, and P. W. Jardon 
Louisiana State University

LSU Digital Commons

LSU Master's Theses

Graduate School

2005

The effect of diets varying in dietary cation-anion difference fed in late gestation and in lactation on sow productivity

Melanie Lynn Roux

Louisiana State University and Agricultural and Mechanical College

Follow this and additional works at: https://digitalcommons.lsu.edu/gradschool_theses

Part of the Animal Sciences Commons

\section{Recommended Citation}

Roux, Melanie Lynn, "The effect of diets varying in dietary cation-anion difference fed in late gestation and in lactation on sow productivity" (2005). LSU Master's Theses. 3379.

https://digitalcommons.lsu.edu/gradschool_theses/3379

This Thesis is brought to you for free and open access by the Graduate School at LSU Digital Commons. It has been accepted for inclusion in LSU

Master's Theses by an authorized graduate school editor of LSU Digital Commons. For more information, please contact gradetd@lsu.edu. 
THE EFFECT OF DIETS VARYING IN DIETARY CATION-ANION DIFFERENCE FED IN LATE GESTATION AND IN LACTATION ON SOW PRODUCTIVITY

\author{
A Thesis \\ Submitted to the Graduate Faculty of the \\ Louisiana State University and \\ Agricultural and Mechanical College \\ in partial fulfillment of the \\ requirements for the degree of \\ Master of Science
}

in

The Interdepartmental Program in Animal, Dairy, and Poultry Sciences

by

Melanie Roux

B. S., Louisiana State University, 2002

December 2005 


\section{ACKNOWLEDGMENTS}

I have enjoyed my time here at LSU. I have made many friends in graduate school. I would like to extend a special thank you to Dr. Southern for allowing me the opportunity to study with him and learn from him. I also need to thank Dr. Southern, Dr. Bidner, and Dr. Williams for serving on my graduate committee. I would like to thank Rebecca, Jack, Allison, Emily, and Hooper for their help with my research. I would like to thank Jerry, Curt, Charles, and the rest of the farm crew at the poultry unit for assisting me whenever I needed help.

In my time here, I have had the pleasure of working with many great people. Thanks to Dr. Johnston, Jason, Rob, Dustin, Brian, Tanika, Ria, Syrena, Danielle, Jeanne, and Jenny. My research would not have been possible without their time, support, and guidance. Last but not least, I would like to thank my parents. My mom and dad have always believed in me and have supported all of my decisions. Without their help and encouragement, I would not be receiving this great honor. 


\section{TABLE OF CONTENTS}

ACKNOWLEDGMENTS ........................................................................................

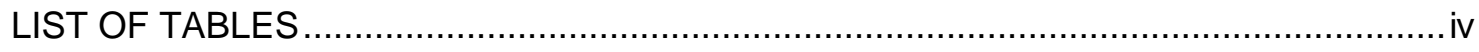

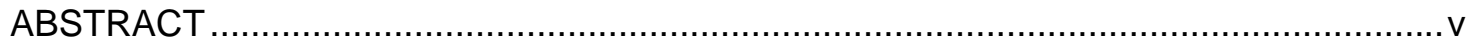

CHAPTER

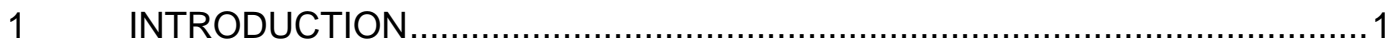

2 REVIEW OF LITERATURE

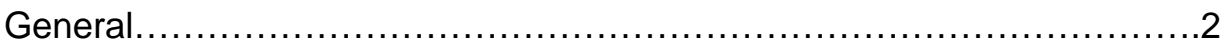

Effect of Dietary Cation-Anion Difference on Plasma Ca Concentrations....3

Effect of Dietary Cation-Anion Difference on Urinary $\mathrm{pH}$....................4 Effect of Dietary Cation-Anion Difference on Sow Growth and Reproductive

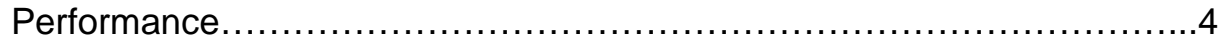

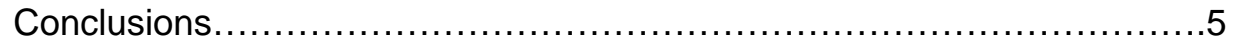

3 THE EFFECT OF DIETS VARYING IN DIETARY CATION-ANION DIFFERENCE FED IN LATE GESTATION AND IN LACTATION ON SOW PRODUCTIVITY

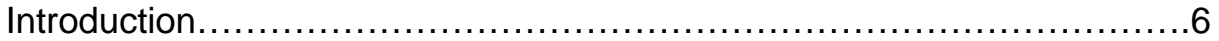

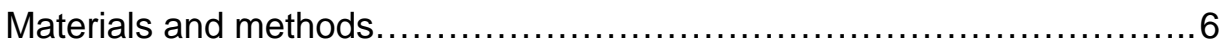

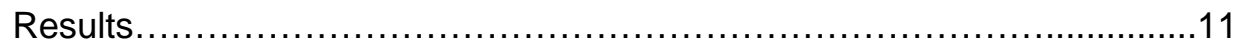

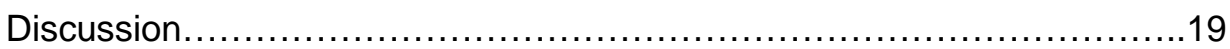

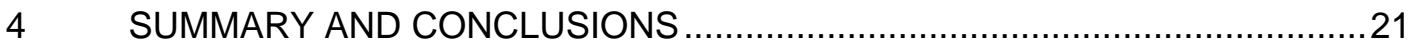

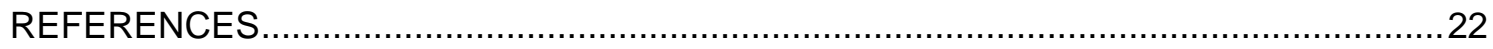

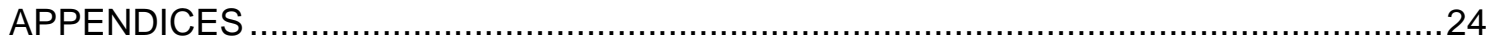

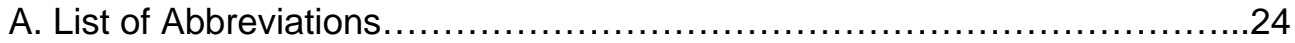

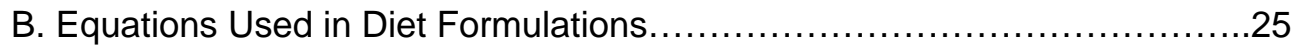

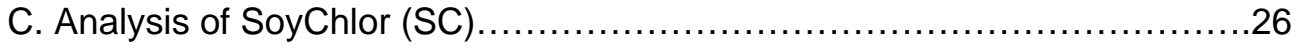

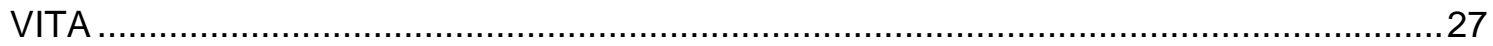




\section{LIST OF TABLES}

3.1 Composition of experimental diets, as-fed basis .9

3.2 The effects of dietary cation-anion difference on sow response variables, Experiment $1 \ldots \ldots 12$

3.3 The effects of dietary cation-anion difference on litter response variables, Experiment $1 \ldots \ldots .13$

3.4 The effects of dietary cation-anion difference on urinary $\mathrm{pH}$ and plasma $\mathrm{Ca}$

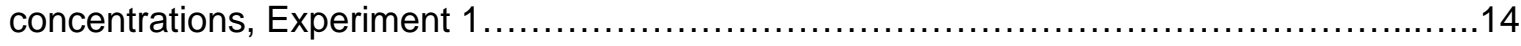

3.5 The effects of dietary cation-anion difference on sow response variables, Experiment $2 \ldots \ldots 15$

3.6 The effects of dietary cation-anion difference on litter response variables, Experiment $2 \ldots \ldots 16$

3.7 The effects of dietary cation-anion difference on sow response variables in subsequent

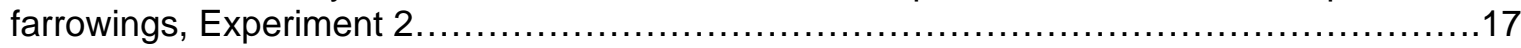

3.8 The effects of dietary cation-anion difference on urinary $\mathrm{pH}$ and plasma Ca concentrations,

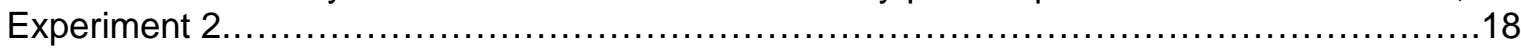




\section{ABSTRACT}

Eighty-six primiparous or multiparous sows and their pigs were used to evaluate the effects of changing dietary cation-anion difference (DCAD) in late gestation and in lactation on sow productivity. Twenty sows were used in Exp. 1, and the dietary treatments consisted of a positive control (PC) corn-soybean meal (C-SBM) diet with four levels of DCAD (140, 99, 75, and 45 $\mathrm{mEq} / \mathrm{kg}$ ). These DCAD's were achieved by four levels of SoyChlor (SC) additive $(0,1.5,2.5$, and 3.5\%). In Exp. 2, 66 sows were used and the dietary treatments consisted of the diets providing DCAD of 140 and $45 \mathrm{mEq} / \mathrm{kg}$. The diets were fed from d 107 of gestation to weaning in Exp. 1 and from d 111 of gestation to weaning in Exp. 2. Sows were allotted based on parity and their farrowing date.

Experiment 1 was a preliminary experiment to determine the level of DCAD that reduced urinary $\mathrm{pH}$. Reducing DCAD did not affect sow reproductive responses. Urinary $\mathrm{pH}$ was linearly decreased $(P<0.001)$ as DCAD decreased in the diet. Reducing DCAD tended to linearly increase $(P=0.15)$ plasma Ca concentrations.

In Exp. 2, reducing DCAD from 140 to $45 \mathrm{mEq} / \mathrm{kg}$ reduced ADFI from d 111 of gestation to d 1 postfarrowing $(P<0.02)$, but ADFI was not affected by DCAD during any other period. Reducing DCAD did not affect reproductive performance of the sows nor litter response variables or plasma Ca. Decreasing DCAD in the diet decreased urinary $\mathrm{pH}(P<0.001)$. Twenty-seven sows fed the PC diet and 21 sows fed the reduced DCAD diet during the previous lactation were evaluated during their subsequent farrowing. Sows that were fed the reduced DCAD diet had increased total number of pigs born $(P<0.08)$ and pigs born alive $(P<0.02)$ in the subsequent farrowing. Changing DCAD had little affect on sow and litter response variables in the current lactation, but it decreased urine $\mathrm{pH}$ $(P<0.001)$, and increased total number of pigs born $(P<0.08)$ and pigs born alive $(P<0.02)$ in the subsequent farrowing. 


\section{CHAPTER 1}

\section{INTRODUCTION}

Feed additives are ingredients that are fed to animals, usually to improve productivity. Acidifiers are feed additives that contain both cations and anions. Cations are minerals with a positive charge. Anions are minerals with a negative charge. Dietary cation-anion difference (DCAD) is the difference between strong fixed cations and strong fixed anions. The differences in ions are used to determine the relationship between strong cations and anions and to predict whether the diet will elicit an acidic or alkaline response when fed to the animal.

Postparturient paresis (milk fever) is a problem in the dairy industry. Altering DCAD is important in dairy nutrition. SoyChlor (SC) is an anionic salt feed additive that contains $\mathrm{CaCl}_{2}$ and $\mathrm{HCl}$. This anionic salt is commonly fed to dairy cattle to make the diet more acidic, thereby preventing milk fever. Individual cases of milk fever differ between herds, but approximately 5 to $7 \%$ of adult dairy cows in the United States are afflicted (Jordan et al., 1993). Cows afflicted with milk fever have reduced feed intake, reduced urination and defecation, and if left untreated, cows become comatose and die (Horst et al., 1997). Milk fever contributes to a severe economic loss because milk production declines in the subsequent lactation (Block, 1984) and it is expensive to treat due to medication and veterinarian visits (Block et al., 1989). Sows usually are not afflicted with milk fever, but urinary tract infections can cause the swine industry to suffer economic loss due to reduced herd health. The purpose of this research was to determine if reducing the dietary cationanion difference in the diets would affect sow productivity when fed during late gestation and in lactation. 


\section{CHAPTER 2}

\section{REVIEW OF LITERATURE}

General

Anionic salts have an increased amount of $\mathrm{Cl}^{-}$and $\mathrm{S}^{-}$in relation to $\mathrm{Na}^{+}$and $\mathrm{K}^{+}$. These four ions are the most important in determining the effects of diet on systemic cation-anion balance (Oetzel et al., 1991). Calcium chloride is an anionic salt routinely added to dairy feed to change the DCAD. Calcium chloride increases dietary $\mathrm{Cl}^{-}$without increasing $\mathrm{Na}^{+}$or $\mathrm{K}^{+}$, thus lowering DCAD. An acidifying diet stimulates the release of cations (especially $\mathrm{Ca}^{2+}$ ) into the blood in order for the animal to maintain homeostatic blood $\mathrm{pH}$. Incorporating anionic salts into the diet helps to increase $\mathrm{Ca}^{2+}$ absorption and bone $\mathrm{Ca}^{2+}$ mobilization. Research indicates that feeding anionic salts acidifies the blood, which restores responsiveness to the parathyroid hormone receptor sites (NRC, 2001).

A commonly fed anionic salt is $\mathrm{CaCl}_{2}$, which is found in the feed additive SC. SoyChlor is a feed additive that supplies the $\mathrm{Cl}^{-}$anion in a carrier that has been extracted from soybean meal, which means it is palatable and high in protein. SoyChlor contains high amounts of Ca (3.40\%) and chloride (9.49\%). Chloride is extremely high in SC because it contains two different sources $\left(\mathrm{CaCl}_{2}\right.$ and $\mathrm{HCl}$ ). Hydrochloric acid is a powerful acidifier, therefore less has to be added to the diet to achieve the same results as a less potent anionic salt (West Central Soy). As early as the 1960's, researchers have observed the importance of manipulating DCAD of feedstuffs to reduce the incidences of postparturient paresis (milk fever) in dairy cows. Milk fever is a metabolic disorder that is triggered by the onset of lactation. After parturition, the cow's Ca stores become imbalanced because the cow's demands for Ca exceed her available resources (Purina Dairy News, 2000). The cow's plasma Ca concentration declines due to Ca being lost to colostrum. Milk fever is more prone to develop when a high DCAD diet is consumed during the last three weeks of pregnancy. Literature suggests that diets high in cations tend to induce milk fever, whereas diets high in anions prevent it (Block et al., 1984; Tucker et al., 1991; Goff et al., 1998; Riond, 2001). 
Research shows that reducing DCAD minimizes the risk of milk fever by lowering intestinal $\mathrm{pH}$, which affects the amount of Ca absorbed (Tucker et al., 1991). Goff et al. (1998) conducted a study involving $\mathrm{HCl}$ and milk fever prevention. They concluded that cows fed $\mathrm{HCl}(1.5 \mathrm{eq} / \mathrm{d})$ had increased feed intake before calving, increased plasma Ca concentrations, and decreased urinary $\mathrm{pH}$ compared to cows fed the control diet. Other research indicates that anionic salts reduce palatability, thereby reducing feed intake (Yen et al., 1981). Goff et al. (1998) indicated that adding $\mathrm{HCl}$ to the diet reduced the risk of milk fever. Two experiments were conducted with cows evaluating the effect of cation-anion balance on milk fever (Block, 1984). In the first study, two diets (+33.05 $\mathrm{mEq} / \mathrm{kg}$ and $-12.85 \mathrm{mEq} / \mathrm{kg} \mathrm{DM}$ ) were fed for two years. They reported no differences in feed intake, but cows fed the cationic diet had $47.4 \%$ greater incidence of milk fever, while cows fed the anionic diet had no incidence of milk fever. In the second study, Block et al. (1989) fed four diets (400, 200, 100, and $50 \mathrm{mEq} / \mathrm{kg} \mathrm{DM}$ ) to prepartum cows. They concluded that feed intake was lower in cows fed $200 \mathrm{mEq} / \mathrm{kg}$ prepartum, but at parturition, feed intake was similar across all treatments. They concluded that decreasing DCAD below the control diet reduced the risk of milk fever. Plasma Ca concentration was increased in the blood when the DCAD was reduced.

Effect of Dietary Cation-Anion Difference on Plasma Ca Concentrations

During gestation, cows lose Ca in relatively small amounts to the excreta and fetus. These losses are not large enough to activate parathyroid hormone mechanisms in the body to increase $\mathrm{Ca}$ concentrations during parturition and lactation. Two hormones, parathyroid hormone and 1,25dihydroxyvitamin $\mathrm{D}_{3}\left[\left(1,25(\mathrm{OH})_{2} \mathrm{D}_{3}\right)\right]$ work together in regulating plasma Ca (Horst et al., 1997) concentrations. When plasma Ca concentrations decline, parathyroid hormone and $1,25(\mathrm{OH})_{2} \mathrm{D}_{3}$ are produced to increase Ca (Horst et al., 1997). Bone is a major contributor to maintaining Ca levels in the blood. If Ca levels are too low, parathyroid hormone stimulates the bone to release Ca that is stored in the lining cells and into the extracellular pool. Before reducing DCAD in dairy cows, nutritionists fed a low Ca diet before calving. This decrease in dietary Ca stimulates parathyroid hormone and $1,25(\mathrm{OH})_{2} \mathrm{D}_{3}$ production to put the cow in positive Ca balance (NRC, 2001). 
After parturition, the cow is at less risk to get milk fever because these Ca homeostatic mechanisms are already active. However, this theory is not practical because a cow needs to eat $20 \mathrm{~g} / \mathrm{d}$ to meet the Ca requirement (West Central Soy). It is difficult to reduce the Ca in a cows diet.

\section{Effect of Dietary Cation-Anion Difference on Urinary $\mathrm{pH}$}

Normal urine $\mathrm{pH}$ in dairy cows is approximately 8 . Including anions in the feed reduces urine $\mathrm{pH}$ to approximately 6 . When feeding an anionic diet, testing urine $\mathrm{pH}$ is the quickest method to determine if the anions are working properly. Riond (2001) reported that a cow's urinary pH needs to be 6.5 to prevent milk fever. Giesy et al. (1997) conducted an experiment with four diets consisting of $30,10,-10$, and $-30 \mathrm{mEq}$ DCAD/100g DM to dry cows. They reported that urine $\mathrm{pH}$ and DCAD have a strong relationship; as DCAD decreases, urinary $\mathrm{pH}$ decreases.

Effect of Dietary Cation-Anion Difference on Sow Growth and Reproductive Performance DeRouchey et al. (2003) fed sows DCAD's of 0, 100, 200, 350, and $500 \mathrm{mEq} / \mathrm{kg}$. Changing DCAD did not affect overall ADFI, but increasing DCAD linearly decreased percent survivability in pigs. Increasing DCAD linearly decreased plasma Ca concentrations and increased urinary $\mathrm{pH}$. Dove and Haydon et al. (1994) fed sows DCAD levels of 130.8, 161.2, and $250.8 \mathrm{mEq} / \mathrm{kg}$ and reported no differences in feed intake, days to estrus, percent survivability in pigs or litter weight gain regardless of dietary treatments. Patience et al. (1987) fed grower pigs a range (-85 to +341 $\mathrm{mEq} / \mathrm{kg}$ ) of DCAD and reported that growth and feed intake were similar for the positive DCAD, but the negative DCAD diets reduced growth and feed intake. Yen et al. (1981) fed three diets; 1) Control, 2) $4 \% \mathrm{CaCl}_{2}+2.22 \% \mathrm{Na}_{5} \mathrm{P}_{3} \mathrm{O}_{10}$, and 3) $4 \% \mathrm{CaCl}_{2}+2.03 \% \mathrm{NaHCO}_{3}$ to finisher pigs. Diet two $\left(4 \% \mathrm{CaCl}_{2}+2.22 \% \mathrm{Na}_{5} \mathrm{P}_{3} \mathrm{O}_{10}\right)$ decreased ADFI which resulted in a decrease in ADG and G:F. Plasma $\mathrm{Cl}^{-}$concentrations were increased from 100 to $112 \mathrm{mmol} / \mathrm{L}$ in pigs fed $4 \% \mathrm{CaCl}_{2}+2.22 \%$ $\mathrm{Na}_{5} \mathrm{P}_{3} \mathrm{O}_{10}$, which may be a reason for the decrease in feed intake. The increased plasma $\mathrm{Cl}^{-}$ concentrations may cause body fluid to become acidogenic, which may reduce feed intake. Austic et al. (1983) fed grower pigs a range of $\operatorname{DCAD}(-100,0,100,200,300$, and $500 \mathrm{mEq} / \mathrm{kg})$ and reported no differences in ADG or G:F when these DCAD diets were fed. 


\section{Conclusions}

Further research is needed before specific recommendations can be made regarding optimal DCAD in rations for swine. Research indicates that feeding anionic diets to prepartum and postpartum dairy cows increases plasma $\mathrm{Ca}$, decreases urinary $\mathrm{pH}$, and does not affect feed intake. More research in swine is needed to determine if reducing DCAD will have positive effects on feed intake and plasma Ca concentrations. 


\section{CHAPTER 3}

\section{THE EFFECT OF DIETS VARYING IN DIETRY CATION-ANION DIFFERENCE FED IN LATE GESTATION AND IN LACTATION ON SOW PRODUCTIVITY}

Introduction

Increasing sow and litter performance during lactation is vital to the swine industry (DeRouchey et al., 2003). Sow litter size has increased during the last decade (Agric. Ltd, 2003). This increase in litter size has increased the demands for milk production. Unlike dairy cows, milk fever is not a major problem in the swine industry. However, during late gestation and lactation, sows can become constipated, which causes difficulties in farrowing. Excess constipation can cause reduced feed intake and this leads to a reduction in milk production, which decreases litter growth. Swine nutritionists are evaluating altering DCAD in sow lactation diets (DeRouchey et al., 1998). Sows are prone to urinary tract infections, and anionic salts are increasingly being fed to sows to reduce urinary $\mathrm{pH}$, which may in turn decrease urinary tract infections (DeRouchey et al., 2003). Calcium chloride $\left(\mathrm{CaCl}_{2}\right)$, potassium chloride $(\mathrm{KCl})$, and magnesium sulfate $\left(\mathrm{MgSO}_{4}\right)$ are mineral compounds that can easily be added to sow diets to decrease urine $\mathrm{pH}$. Research shows that by incorporating anionic salts into the diet of prepartum dairy cows, urinary $\mathrm{pH}$ decreases, $\mathrm{Ca}$ metabolism is improved, and milk fever is prevented. However, minimal research has been conducted on DCAD and its effects on sows during lactation and on reproductive performance. Therefore, the objective of this experiment was to determine the effects of decreasing DCAD on sow productivity.

\section{Materials and Methods}

\section{General}

The Louisiana State University (LSU) Agricultural Center Animal Care and Use Committee approved all methods used in these experiments. Primiparous and multiparous Yorkshire and crossbred (Yorkshire $x$ Landrace or Yorkshire $x$ Duroc) sows from the LSU Agricultural Center Swine Unit were allotted to dietary treatments on d 107 of gestation for Exp.1 and d 111 of gestation for Exp. 2. 
Before starting dietary treatments, all sows were fed a typical C-SBM gestation diet that met or exceeded the nutrient requirements (NRC, 1998) of gestating sows. The sows were allotted to their respective treatments within each group based on parity and the date of $d 107$ of gestation for Exp.1 and d 111 of gestation for Exp.2.

Diets fed during both experiments were formulated on a total AA basis from analyzed AA values for SoyChlor (SC, West Central Soy; Appendix C) and NRC (1998) values for corn (C) and soybean meal (SBM). Proximate analysis and NDF were conducted on SC for calculation of ME. Metabolizable energy was calculated using Noblet's equations (Appendix B). The equation that was used to determine DCAD levels in the diets is in Appendix B. The diets were formulated to 3,300 $\mathrm{kcal} / \mathrm{kg} \mathrm{ME}$ and $1.02 \%$ Lys. The diets met or exceeded $105 \%$ of the requirement $(\mathrm{NRC}, 1998)$ for lactating sows anticipating no lactation weight loss with pigs gaining $250 \mathrm{~g} / \mathrm{d}$. Dietary treatments (Table 3.1) for Exp. 1 consisted of a positive control (PC) C-SBM diet and a C-SBM diet plus 1.5, 2.5, and 3.5\% SC to achieve DCAD of 140, 99, 75, and $45 \mathrm{mEq} / \mathrm{kg}$. In Exp. 2, dietary treatments consisted of the same PC C-SBM (140 mEq/kg) and C-SBM diet with reduced DCAD (45 mEq/kg). Sows were weighed and moved into the farrowing house on their respective date of gestation, and from this point forward, the treatment diets were started and continued through weaning. Upon entering the farrowing house until d 1 postfarrowing, the sows were fed approximately $2.5 \mathrm{~kg} / \mathrm{d}$ (asfed basis). On d 1 postfarrowing, sows and feed containers were weighed to determine weight change per day and ADFI from d 107 of gestation in Exp.1 and d 111 of gestation in Exp. 2 to $d 1$ postfarrowing.

The farrowing house is an environmentally controlled building with 28 individual farrowing crates and an under-floor flush system. Each farrowing crate is $1.5 \times 2.1 \mathrm{~m}$, with a cast iron-floor for the sow and plastic slotted floor for the pigs. Each crate contains a stainless steel feeder and nipple waterer for the sows and a nipple waterer for the pigs. Within $24 \mathrm{~h}$ of farrowing, litters were weighed, ear-notched, given a 1-mL shot of iron dextran (Phoenix Scientific Inc., St. Joseph, MO), umbilical cords were sprayed with iodine, and needle teeth were clipped. 
During processing, litters were also adjusted by cross-fostering within respective treatments to approximately 10 pigs per litter if necessary. From d 1 postfarrowing to weaning, the sows were fed three times daily. In the four farrowing groups, pigs were weaned at an average of $19,18,16$, and $15 \mathrm{~d}$. All pigs were weaned on the same day regardless of their farrowing date. At weaning, the sows and feed containers were weighed to determine lactation weight change per day and lactation ADFI from d 1 postfarrowing to weaning. Within $2 \mathrm{~d}$ of weaning, sows were checked daily for signs of estrus. In Exp. 1, 7 sows did not return to estrus (one from PC; six from the reduced DCAD diets) within 7 d postweaning. In Exp. 2, there were six sows fed the PC and two sows fed the reduced DCAD diet that did not return to estrus within $7 \mathrm{~d}$ postweaning.

Blood Collection

On d 1 postfarrowing, approximately $6 \mathrm{~mL}$ of blood was collected from the anterior vena cava with a 16 gauge needle and placed into a 10-mL tube (BD Vacutainer, Franklin Lakes, NJ) that contained no additive. The sample of blood was immediately centrifuged in an Allegra 6R Centrifuge (Beckman Coulter, Inc., Palo Alto, CA.) at $1,500 \mathrm{~g}$ at $4^{\circ} \mathrm{C}$ for $25 \mathrm{~min}$. After centrifugation, the plasma was poured into $5 \mathrm{~mL}$ tubes and stored at $20^{\circ} \mathrm{C}$ until analysis. The plasma samples were analyzed using flame atomic absorption spectrophotometry (Perkin Elmer Analyst 300) after a 1:100 dilution with $0.5 \%$ lanthanum oxide. For Exp. 1, the samples were analyzed once whereas, in Exp. 2, samples were analyzed twice and then averaged to get a mean for plasma Ca concentration. Urine Collection

A midstream urine sample was collected from each sow for $\mathrm{pH}$ determination when sows averaged $11 \pm 2$ d postfarrowing in Exp. 1 and $12 \pm 3 d$ postfarrowing in Exp. 2. Two urine samples were collected from each sow and averaged together on two consecutive days. Each urine collection period lasted $3 \mathrm{~d}$. The $\mathrm{pH}$ was determined by a $\mathrm{pH} / \mathrm{mV} /$ thermometer with an attached islet sensor $\mathrm{pH}$ probe.

Sow Response Variables

The sow response variables included weight at $d 107$ and d 111 of gestation, 
Table 3.1. Composition of experimental diets, as-fed basis

Dietary cation-anion difference, $\mathrm{mEq} / \mathrm{kg}^{\mathrm{a}}$

\begin{tabular}{|c|c|c|c|c|}
\hline Item & $140^{\mathrm{b}, \mathrm{c}}$ & $99^{b}$ & $75^{b}$ & $45^{\mathrm{b}, \mathrm{c}}$ \\
\hline \multicolumn{5}{|l|}{ Ingredient, \% } \\
\hline Corn & 66.007 & 65.081 & 64.464 & 63.848 \\
\hline Soybean meal & 28.090 & 27.788 & 27.586 & 27.384 \\
\hline SoyChlor $16-7^{a}$ & --------- & 1.500 & 2.500 & 3.500 \\
\hline Monocalcium phosphate & 2.006 & 1.999 & 1.995 & 1.990 \\
\hline Limestone & 1.528 & 1.400 & 1.315 & 1.229 \\
\hline Dry fat & 1.168 & 1.032 & 0.940 & 0.849 \\
\hline Vitamin premix $^{d}$ & 0.500 & 0.500 & 0.500 & 0.500 \\
\hline Salt & 0.500 & 0.500 & 0.500 & 0.500 \\
\hline Choline chloride, $60 \%$ & 0.100 & 0.100 & 0.100 & 0.100 \\
\hline Trace mineral premix ${ }^{\mathrm{e}}$ & 0.100 & 0.100 & 0.100 & 0.100 \\
\hline \multicolumn{5}{|l|}{ Calculated composition: } \\
\hline $\mathrm{ME}, \mathrm{kcal} / \mathrm{kg}$ & 3,300 & 3,300 & 3,300 & 3,300 \\
\hline Lysine, \% & 1.020 & 1.020 & 1.020 & 1.020 \\
\hline Methionine, \% & 0.300 & 0.302 & 0.303 & 0.304 \\
\hline Tryptophan, \% & 0.222 & 0.221 & 0.220 & 0.220 \\
\hline Sodium, \% & 0.216 & 0.218 & 0.219 & 0.219 \\
\hline Potassium, \% & 0.823 & 0.822 & 0.822 & 0.821 \\
\hline Chloride, \% & 0.350 & 0.493 & 0.587 & 0.681 \\
\hline Sulfur, \% & 0.210 & 0.217 & 0.221 & 0.225 \\
\hline Calcium, \% & 1.000 & 1.000 & 1.000 & 1.000 \\
\hline Magnesium, \% & 0.204 & 0.199 & 0.197 & 0.194 \\
\hline Phosphorus, \% & 0.800 & 0.800 & 0.800 & 0.800 \\
\hline $\operatorname{DCAD}^{f}$ & 140 & 99 & 75 & 45 \\
\hline \multicolumn{5}{|c|}{ 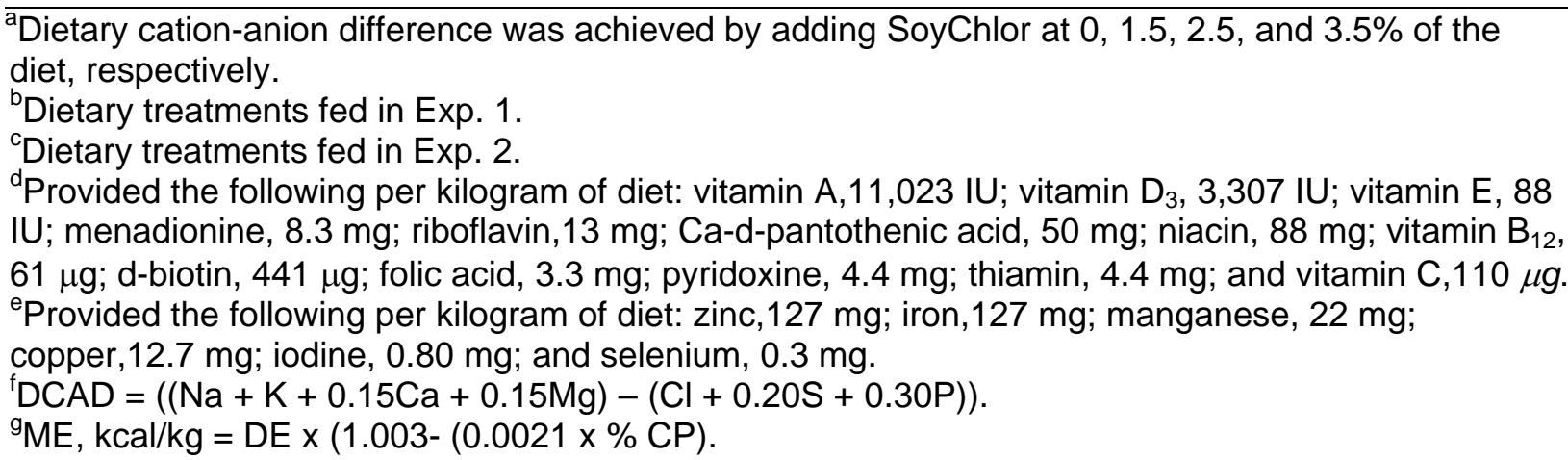 } \\
\hline
\end{tabular}


d 1 postfarrowing, and at weaning; weight change per day from prefarrowing, lactation, and overall; ADFI, ADG, and G:F prefarrowing, during lactation, and overall; lactation length, days to estrus, total number pigs born, pigs born alive, stillbirths, and mummies.

Litter Response Variables

The litter response variables were live and total birth weights, number weaned, number nursed, initial litter weight after cross-fostering, initial litter weight adjusted for mortality, final litter weight, litter weight gain, and percent survivability.

Statistical Analysis

Data were analyzed by ANOVA procedures appropriate for a randomized complete block design (Steel and Torrie, 1980) using the GLM procedures of SAS (SAS Inst. Inc., Cary, NC). All data were analyzed with the sow as the experimental unit. In both experiments, covariates were used to analyze some response variables, but orthogonal contrast statements (linear and quadratic) were also used (Exp. 1 only) to analyze treatment differences. There were no covariates used for the following data: sow 107 and 111 d weight, G:F from d 107 and 111 of gestation to d 1 postfarrowing, during lactation, and overall; lactation length, total number pigs born, pigs born alive, stillbirths, mummies, live and total birth weights, initial litter weight after cross-fostering, and initial litter weight adjusted for mortality. Sow $\mathrm{d} 107$ and 111 of gestation weight was used as a covariate for sow $\mathrm{d} 1$ postfarrowing and weaning weight; prefarrrowing, lactation, and overall weight change per day; ADG from d 107 and 111 of gestation to d 1 postfarrowing, during lactation, and overall, and ADFI from d 107 and 111 of gestation to $d 1$ postfarrowing. Sow d 111 weight affected $(P<0.02)$ ADFI from d 111 of gestation to $d 1$ postfarrowing. Lactation length was used as a covariate for ADFI during lactation and overall, number of pigs nursed, final litter weight, litter weight gain, days to estrus, and percent survivability. Initial litter weight after cross-fostering and lactation length were covariates for final litter weight and litter weight gain. Neither of the covariates were significant $(P>0.10)$ for the response variables final litter weight and litter weight gain. Number of pigs nursed was used as a covariate for number of pigs weaned. For both experiments, an alpha level of 0.10 was used to 
indicate significant treatment differences.

Results

\section{Experiment 1}

Experiment 1 was a preliminary study conducted to determine the optimum level of SC needed to change DCAD to reduce urinary $\mathrm{pH}$. The results from Exp. 1 indicate that DCAD had little effect on sow (Table 3.2) and litter response (Table 3.3) variables. As DCAD decreased, ADFI during lactation $(P<0.08)$ and overall $(P<0.06)$ increased linearly. As DCAD decreased in the diets, urinary $\mathrm{pH}$ linearly decreased $(P<0.001)$. Reducing DCAD tended to linearly increase $(P=$ 0.15) plasma Ca concentrations. The results indicate that changing DCAD to $45 \mathrm{mEq} / \mathrm{kg}$ had the greatest decrease in urine $\mathrm{pH}$ (Table 3.4), and this DCAD was used in Exp. 2.

Experiment 2

Sow Response Variables. In Exp. 2 (Table 3.5), ADFI from d 111 of gestation to $d 1$ postfarrowing decreased as DCAD decreased $(P<0.02)$. However, ADFI during lactation and overall were not affected $(P>0.10)$ by DCAD. Neither ADG nor G:F were affected by DCAD $(P>$ 0.10). Sows fed the reduced DCAD diet tended to have reduced weight change during prefarrowing (-18.71 vs. -15.11), lactation (-8.67 vs. -6.84$)$, and overall (-27.42 vs. -21.94$)$, but the effects were not significant $(P>0.10)$. Sows fed the PC diet had decreased days to estrus compared to sows fed the reduced DCAD diet $(P<0.04)$. The DCAD diet did not affect total number pigs born, pigs born alive, stillbirths, or mummies $(P>0.10)$.

Litter Response Variables. Reducing DCAD (Table 3.6) tended to result in a higher number of pigs weaned (8.79 vs. 8.43), but the effect was not significant $(P=0.18)$. Reducing DCAD tended to increase initial litter weight adjusted for mortality, but the effect was not significant $(P=0.13)$.

Also, percent survivability of pigs nursing from sows fed the reduced DCAD diet tended to be higher (89.42 vs. 85.77), but the effect was not significant $(P=0.19)$. Feeding reduced DCAD diets did not affect live and total birth weights, number nursed, initial litter weight after cross-fostering, final litter weight, or litter weight gain $(P>0.10)$. Sows fed reduced DCAD $(P<0.001)$ had decreased urinary 
Table 3.2. The effects of dietary cation-anion difference on sow response variables, Experiment $1^{a}$

\begin{tabular}{|c|c|c|c|c|c|c|c|c|}
\hline \multirow[b]{2}{*}{ Response variables } & \multicolumn{4}{|c|}{ Dietary cation-anion difference, $\mathrm{mEq} / \mathrm{kg}^{\mathrm{b}}$} & \multicolumn{4}{|c|}{$P=F$} \\
\hline & 140 & 99 & 75 & 45 & SEM & Linear & Quadratic & $P$ value \\
\hline Parity & 1.50 & 2.00 & 2.33 & 2.00 & 0.58 & 0.46 & 0.48 & \\
\hline d 107 wt, kg & 252.65 & 266.56 & 268.75 & 267.17 & 18.78 & 0.58 & 0.70 & \\
\hline 24h wt, kg ${ }^{\mathrm{i}, \mathrm{k}}$ & 247.00 & 252.54 & 258.05 & 251.48 & 5.94 & 0.44 & 0.47 & 0.57 \\
\hline Weaning wt, kg ${ }^{\mathrm{i}, \mathrm{k}}$ & 241.22 & 246.76 & 252.54 & 244.36 & 6.78 & 0.48 & 0.46 & 0.64 \\
\hline Pre-farr BW change, $\mathrm{kg}^{\mathrm{f}, \mathrm{i}, \mathrm{k}}$ & -16.20 & -10.66 & -5.15 & -11.71 & 5.94 & 0.75 & 0.54 & 0.57 \\
\hline Lactation BW change, $\mathrm{kg}^{\mathrm{g}, \mathrm{i}, \mathrm{k}}$ & -5.78 & -5.78 & -5.51 & -7.12 & 3.12 & 0.81 & 0.78 & 0.98 \\
\hline Overall BW change, $\mathrm{kg}^{\mathrm{h}, \mathrm{i}, \mathrm{k}}$ & -21.98 & -16.44 & -10.65 & -18.83 & 6.78 & 0.85 & 0.50 & 0.78 \\
\hline ADG $1, \mathrm{~kg}^{\mathrm{c}, \mathrm{i}, \mathrm{k}}$ & -1.76 & -1.23 & -0.54 & -1.75 & 0.59 & 0.92 & 0.36 & 0.38 \\
\hline ADG 2, $\mathrm{kg}^{\mathrm{d}, \mathrm{i}, \mathrm{k}}$ & -0.33 & -0.32 & -0.33 & -0.35 & 0.16 & 0.94 & 0.89 & 0.99 \\
\hline OADG, $\mathrm{kg}^{\mathrm{e}, \mathrm{i}, \mathrm{k}}$ & -0.81 & -0.61 & -0.36 & -0.69 & 0.24 & 0.79 & 0.44 & 0.56 \\
\hline ADFI $1, \mathrm{~kg}^{\mathrm{c}, \mathrm{i}, \mathrm{k}}$ & 2.34 & 2.34 & 2.63 & 2.40 & 0.12 & 0.51 & 0.46 & 0.32 \\
\hline ADFI 2, $\mathrm{kg}^{\mathrm{d}, \mathrm{j}, \mathrm{k}}$ & 5.03 & 5.40 & 6.31 & 6.09 & 0.53 & 0.08 & 0.37 & 0.19 \\
\hline OADFI, $\mathrm{kg}^{\mathrm{e}, \mathrm{j}, \mathrm{k}}$ & 4.16 & 4.44 & 4.85 & 5.00 & 0.39 & 0.06 & 0.84 & 0.29 \\
\hline $\mathrm{G}: \mathrm{F} 1, \mathrm{~kg}^{\mathrm{c}}$ & -0.660 & -0.566 & -0.302 & -0.801 & 0.29 & 0.90 & 0.35 & \\
\hline $\mathrm{G}: F 2, \mathrm{~kg}^{\mathrm{d}}$ & -0.060 & -0.059 & -0.049 & -0.059 & 0.03 & 0.93 & 0.86 & \\
\hline $\mathrm{OG}: \mathrm{F}, \mathrm{kg}^{\mathrm{e}}$ & -0.178 & -0.140 & -0.083 & -0.152 & 0.06 & 0.60 & 0.38 & \\
\hline Lactation length, $d$ & 19.33 & 18.33 & 18.00 & 21.20 & 0.90 & 0.20 & 0.04 & \\
\hline Days to estrus, $\mathrm{d}^{\mathrm{j}, \mathrm{k}}$ & 4.21 & 4.71 & 4.70 & 4.49 & 0.48 & 0.93 & 0.22 & 0.77 \\
\hline Total pigs born & 11.33 & 11.00 & 11.50 & 12.00 & 1.73 & 0.74 & 0.82 & \\
\hline Pigs born alive & 10.67 & 9.00 & 9.00 & 10.20 & 1.36 & 0.82 & 0.33 & \\
\hline Stillbirths & 0.67 & 2.00 & 1.83 & 0.80 & 0.64 & 0.93 & 0.10 & \\
\hline Mummies & 0.00 & 0.00 & 0.67 & 1.00 & 0.26 & 0.005 & 0.54 & \\
\hline
\end{tabular}

${ }^{a} n=6,3,6$, and 5 for $140,99,75$, and 45 dietary cation-anion difference, respectively.

${ }^{b}$ Dietary cation-anion difference was achieved by adding SoyChlor at $0,1.5,2.5$, and $3.5 \%$ of the diet, respectively.

${ }^{c} A D G 1, A D F I$, and GF 1 are measurements taken from d 107 until d 1 postfarrowing.

${ }^{\mathrm{d} A D G} 2$, ADFI 2, and GF 2 are measurements taken form $\mathrm{d} 1$ postfarrowing until weaning.

${ }^{\circ} \mathrm{OADG}, \mathrm{OADFI}$, and OGF are measurements taken from d 107 until weaning.

${ }^{f}$ Pre-farrowing BW change = the difference in sow wt at d 1 postfarrowing and sow wt at $d 107$ of gestation.

'Lactation BW change $=$ the difference in sow weaning wt and sow wt at $\mathrm{d} 1$ postfarrowing.

${ }^{\mathrm{h}}$ Overall BW change $=$ the difference in sow weaning wt and sow wt at $\mathrm{d} 107$ of gestation.

'Treatment means were reported using sow wt at $\mathrm{d} 107$ of gestation as a covariate.

${ }^{j}$ Treatment means were reported using lactation length as a covariate.

${ }^{\mathrm{k}} P$ values are only reported for the response variables that used covariates. 
Table 3.3. The effects of dietary cation-anion difference on litter response variables, Experiment $1^{\mathrm{a}}$

Dietary cation-anion difference, $\mathrm{mEq} / \mathrm{kg}^{\mathrm{b}} \quad \mathrm{P}=\mathrm{F}$

\begin{tabular}{|c|c|c|c|c|c|c|c|c|}
\hline Response variables & 140 & 99 & 75 & 45 & SEM & Linear & Quadratic & $P$ value \\
\hline Birth wt live, $\mathrm{kg}$ & 16.51 & 14.64 & 13.33 & 16.49 & 1.90 & 0.87 & 0.22 & \\
\hline Birth wt total, kg & 17.26 & 17.13 & 15.78 & 17.67 & 2.16 & 0.99 & 0.66 & \\
\hline Nursed $d^{f, h}$ & 10.46 & 9.39 & 9.20 & 9.36 & 1.26 & 0.81 & 0.22 & 0.82 \\
\hline Weaned $^{\mathrm{j}}$ & 8.75 & 8.24 & 9.03 & 8.52 & 0.46 & 0.84 & 0.26 & 0.70 \\
\hline Initial litter wt, $\mathrm{kg}(\mathrm{ACF})^{\mathrm{c}}$ & 16.80 & 14.64 & 13.15 & 16.41 & 1.69 & 0.72 & 0.14 & \\
\hline Initial litter wt, $\mathrm{kg}(\mathrm{AM})^{\mathrm{d}}$ & 14.81 & 12.81 & 12.37 & 14.67 & 1.61 & 0.90 & 0.22 & \\
\hline Final litter wt, $\mathrm{kg}^{\mathrm{i}}$ & 44.01 & 45.27 & 49.16 & 49.96 & 4.65 & 0.37 & 0.17 & 0.71 \\
\hline Litter wt gain, $\mathrm{kg} / \mathrm{d}^{\mathrm{e}, \mathrm{i}}$ & 1.58 & 1.61 & 1.81 & 1.85 & 0.21 & 0.40 & 0.38 & 0.69 \\
\hline Survival, $\%^{\mathrm{h}}$ & 90.22 & 84.69 & 94.71 & 89.32 & 4.97 & 0.77 & 0.89 & 0.55 \\
\hline
\end{tabular}

${ }_{\mathrm{a}}=6,3,6$, and 5 for $140,99,75$, and 45 dietary cation-anion difference, respectively.

${ }^{\mathrm{b}}$ Dietary cation-anion difference was achieved by adding SoyChlor at $0,1.5,2.5$, and $3.5 \%$ of the diet, respectively.

${ }^{c} \mathrm{ACF}=$ after cross-fostering.

${ }^{\mathrm{d}} \mathrm{AM}=$ initial litter weights were adjusted for mortality once cross-fostering had occured.

${ }^{\mathrm{e}}$ Litter wt gain $=($ final litter wt - initial litter wt (AM)) / lactation length.

${ }^{f}$ Nursed $=$ the number of pigs the sow nursed after cross-fostering occurred.

${ }^{9}$ Survival $\%=$ pigs weaned $/$ pigs nursed * 100 .

${ }^{\mathrm{h}}$ Treatment means were reported using lactation length as a covariate.

'Treatment means were reported using initial litter wt (ACF) as a covariate.

${ }^{\mathrm{j}}$ Treatment means were reported using nursed as a covariate. 
Table 3.4. The effects of dietary cation-anion difference on urinary $\mathrm{pH}$ and plasma $\mathrm{Ca}$ concentrations, Experiment $1^{\mathrm{a}}$

\begin{tabular}{lccccccc} 
& \multicolumn{3}{c}{ Dietary cation-anion difference, $\mathrm{mEq} / \mathrm{kg}^{\mathrm{b}}$} & \multicolumn{3}{c}{$\mathrm{P}=\mathrm{F}$} \\
\hline Response variables & 140 & 99 & 75 & 45 & SEM & Linear & Quadratic \\
\hline & & & & & & & \\
\hline Urinary $\mathrm{pH}^{\mathrm{c}}$ & 7.28 & 7.13 & 6.85 & 6.21 & 0.17 & 0.001 & 0.23 \\
Plasma Ca, $\mathrm{mg} / \mathrm{dL}$ & 7.70 & 7.70 & 7.97 & 7.98 & 0.16 & 0.15 & 0.97 \\
\hline
\end{tabular}

${ }^{a} n=6,3,6$, and 5 for $140,99,75$, and 45 dietary cation-anion difference, respectively.

${ }^{b}$ Dietary cation-anion difference was achieved by adding SoyChlor at $0,1.5,2.5$, and $3.5 \%$ of the diet, respectively.

${ }^{\mathrm{c}}$ Urinary $\mathrm{pH}=$ an average of two urine samples were taken on two consecutive days from each sow $11 \pm$ 2 d postfarrowing. 
Table 3.5. The effects of dietary cation-anion difference on sow response variables, Experiment $2^{\mathrm{a}}$

Dietary cation-anion difference, $\mathrm{mEq} / \mathrm{kg}^{\mathrm{b}}$

\begin{tabular}{|c|c|c|c|c|c|}
\hline Response variables & Covariates & 140 & 45 & SEM & $P$ value \\
\hline Parity & & 1.45 & 1.58 & 0.26 & 0.74 \\
\hline d $111 \mathrm{wt}, \mathrm{kg}$ & & 261.85 & 270.18 & 6.25 & 0.35 \\
\hline $24 \mathrm{~h} w \mathrm{t}, \mathrm{kg}$ & Sow d $111 \mathrm{wt}$ & 247.42 & 251.01 & 1.98 & 0.21 \\
\hline Weaning wt, kg & Sow d $111 \mathrm{wt}$ & 238.62 & 244.08 & 2.51 & 0.13 \\
\hline Pre-farr BW change, $\mathrm{kg}^{\dagger}$ & Sow d $111 \mathrm{wt}$ & -18.71 & -15.11 & 1.98 & 0.21 \\
\hline Lactation BW change, $\mathrm{kg}^{\mathrm{g}}$ & Sow d $111 \mathrm{wt}$ & -8.67 & -6.84 & 1.94 & 0.51 \\
\hline Overall BW change, $\mathrm{kg}^{\mathrm{h}}$ & Sow d $111 \mathrm{wt}$ & -27.42 & -21.94 & 2.51 & 0.13 \\
\hline ADG $1, \mathrm{~kg}^{\mathrm{c}}$ & Sow d 111 wt & -3.50 & -3.07 & 0.48 & 0.53 \\
\hline ADG 2. $\mathrm{kg}^{\mathrm{d}}$ & Sow d $111 \mathrm{wt}$ & -0.51 & -0.44 & 0.12 & 0.67 \\
\hline OADG, $\mathrm{kg}^{\mathrm{e}}$ & Sow d $111 \mathrm{wt}$ & -1.25 & -1.00 & 0.12 & 0.13 \\
\hline ADFI $1, \mathrm{~kg}^{\mathrm{c}}$ & Sow d 111 wt & 2.80 & 2.06 & 0.22 & 0.02 \\
\hline ADFI 2, $\mathrm{kg}^{\mathrm{d}}$ & Lactation length & 5.04 & 5.55 & 0.24 & 0.15 \\
\hline OADFI, $\mathrm{kg}^{\mathrm{e}}$ & Lactation length & 4.44 & 4.65 & 0.19 & 0.43 \\
\hline $\mathrm{G}: \mathrm{F} 1, \mathrm{~kg}^{\mathrm{c}}$ & & -1.88 & -2.20 & 0.53 & 0.67 \\
\hline $\mathrm{G}: \mathrm{F} 2, \mathrm{~kg}^{\mathrm{d}}$ & & -0.11 & -0.09 & 0.03 & 0.58 \\
\hline $\mathrm{OG}: \mathrm{F}, \mathrm{kg}^{\mathrm{e}}$ & & -0.31 & -0.24 & 0.04 & 0.18 \\
\hline Lactation length, $d$ & & 16.24 & 16.30 & 0.46 & 0.93 \\
\hline Days to estrus, $d$ & Lactation length & 4.19 & 4.58 & 0.12 & 0.04 \\
\hline Total number pigs born & & 12.09 & 11.64 & 0.62 & 0.61 \\
\hline Pigs born alive & & 10.15 & 10.18 & 0.61 & 0.97 \\
\hline Stillbirths & & 1.55 & 1.27 & 0.22 & 0.39 \\
\hline Mummies & & 0.39 & 0.18 & 0.13 & 0.25 \\
\hline
\end{tabular}

${ }^{\mathrm{a} D a t a}$ are means of 33 sows per treatment over three farrowing groups.

${ }^{b}$ Dietary cation-anion difference was achieved by adding SoyChlor at 0 and $3.5 \%$ of the diet.

${ }^{\mathrm{c}} \mathrm{ADG} 1, \mathrm{ADFI} 1$, and GF 1 are measurements taken from d 111 until farrowing.

${ }^{d} A D G$ 2, ADFI 2, and GF 2 are measurements taken on d 1 postfarrowing until weaning.

${ }^{O} O A D G, O A D F I$, and OGF are measurements taken from d 111 until weaning.

${ }^{f}$ Pre-farrowing BW change = the difference in sow wt at d 1 postfarrowing and sow wt at $d 111$ of gestation.

gLactation BW change $=$ the difference in sow weaning wt and sow wt at d 1 postfarrowing.

${ }^{\mathrm{h}}$ Overall BW change $=$ the difference in sow weaning wt and sow wt at d 111 of gestation. 
Table 3.6. The effects of dietary cation-anion difference on litter response variables, Experiment $2^{\mathrm{a}}$

Dietary cation-anion difference, $\mathrm{mEq} / \mathrm{kg}^{\mathrm{b}}$

\begin{tabular}{|c|c|c|c|c|c|}
\hline Response variables & Covariates & 140 & 45 & SEM & $P$ value \\
\hline Birth wt live, $\mathrm{kg}$ & & 15.15 & 15.36 & 0.81 & 0.85 \\
\hline Birth wt total, kg & & 17.30 & 16.94 & 0.78 & 0.75 \\
\hline Weaned & Nursed & 8.43 & 8.79 & 0.19 & 0.18 \\
\hline Nursed ${ }^{f}$ & Lactation length & 9.61 & 10.02 & 0.30 & 0.33 \\
\hline Initial litter wt, $\mathrm{kg}(\mathrm{ACF})^{\mathrm{c}}$ & & 14.63 & 15.44 & 0.54 & 0.29 \\
\hline Initial litter wt, $k g(A M)^{d}$ & & 12.77 & 13.98 & 0.56 & 0.13 \\
\hline Final litter wt, kg & Lact d / ILW(ACF) & 44.55 & 45.24 & 1.24 & 0.70 \\
\hline Litter wt gain, $\mathrm{kg}^{\mathrm{e}}$ & Lact d / ILW(ACF) & 1.91 & 1.96 & 0.07 & 0.62 \\
\hline Survival $\%^{g}$ & Lactation length & 85.77 & 89.42 & 1.95 & 0.19 \\
\hline
\end{tabular}

${ }^{\mathrm{a}}$ Data are means of 33 sows per treatment over three farrowing groups.

${ }^{b}$ Dietary cation-anion difference was achieved by adding SoyChlor at 0 and $3.5 \%$ of the diet.

${ }^{\mathrm{c}} \mathrm{ACF}=$ after cross-fostering.

${ }^{\mathrm{d}} \mathrm{AM}=$ initial litter weights adjusted for mortality once cross-fostering had occured.

e Litter wt gain $=($ final litter wt - initial litter wt (AM)) $/$ lactation length .

${ }^{f}$ Nursed $=$ the number of pigs the sow nursed after cross-fostering occurred.

${ }^{9}$ Survival \% = pigs weaned / pigs nursed * 100. 
Table 3.7. The effects of dietary cation-anion difference on sow response variables in subsequent farrowings, Experiment 2

Dietary cation-anion difference, $\mathrm{mEq} / \mathrm{kg}^{\mathrm{a}}$

\begin{tabular}{|c|c|c|c|c|}
\hline Response variables & 140 & 45 & SEM & $P$ value \\
\hline $\mathrm{n}$ & 27 & 21 & & \\
\hline Total number pigs born & 9.63 & 11.48 & 0.73 & 0.08 \\
\hline Pigs born alive & 8.26 & 10.38 & 0.59 & 0.02 \\
\hline Stillbirths & 1.00 & 0.86 & 0.26 & 0.71 \\
\hline Mummies & 0.41 & 0.26 & 0.16 & 0.59 \\
\hline Mortality $^{b}$ & 0.61 & 0.97 & 0.18 & 0.19 \\
\hline Birth wt live, $\mathrm{kg}^{\mathrm{c}}$ & 14.32 & 16.09 & 1.21 & 0.31 \\
\hline Birth wt total, $\mathrm{kg}^{\mathrm{d}}$ & 15.69 & 17.07 & 1.21 & 0.43 \\
\hline
\end{tabular}

${ }^{2}$ Dietary cation-anion difference was achieved by adding SoyChlor at 0 and $3.5 \%$ of the diet and was fed during the previous lactation.

${ }^{\mathrm{b}}$ Mortality was analyzed using pigs born alive as a covariate.

${ }^{c}$ Birth wt live $=$ is the wt of all pigs born alive.

${ }^{\mathrm{d}}$ Birth wt total $=$ is the wt of all pigs born alive and dead. 
Table 3.8. The effects of dietary cation-anion difference on urinary $\mathrm{pH}$ and plasma $\mathrm{Ca}$ concentrations, Experiment $2^{a}$

Dietary cation-anion difference, $\mathrm{mEq} / \mathrm{kg}^{\mathrm{b}}$

\begin{tabular}{lllll}
\hline \multicolumn{1}{c}{ Response variables } & 140 & 45 & SEM & $P$ value \\
\hline & & & & \\
\hline Urinary $\mathrm{pH}^{\mathrm{c}}$ & 7.03 & 5.66 & 0.07 & $<.0001$ \\
Plasma Ca, $\mathrm{mg} / \mathrm{dL}^{\mathrm{d}}$ & 9.00 & 8.92 & 0.20 & 0.65 \\
\hline
\end{tabular}

${ }^{\mathrm{a}}$ Data are means of 33 sows per treatment over three farrowing groups.

${ }^{\mathrm{b}}$ Dietary cation-anion difference was achieved by adding SoyChlor at 0 and $3.5 \%$ of the diet.

'Urinary $\mathrm{pH}=$ an average of two urine samples taken on two consecutive days from each sow $12 \pm 3 \mathrm{~d}$ postfarrowing.

${ }^{\mathrm{d}}$ Plasma Ca concentration is the mean from a sample that was analyzed two times. 
pH compared to sows fed the PC diet (Table 3.8). Plasma Ca concentrations were not affected $(P>$ 0.10) by DCAD (Table 3.8).

There were 27 sows fed the PC diet and 21 sows fed the reduced DCAD diet that were evaluated during their next farrowing (Table 3.7). The sows that were fed the reduced DCAD diet during the previous lactation had an increased total number of pigs born $(P<0.08)$ and pigs born alive $(P<0.02)$. Reducing DCAD did not affect stillbirths, mummies, mortality, or live and total birth weights $(P>0.10)$.

\section{Experiment 1}

\section{Discussion}

The results from Exp. 1 showed that feeding diets with reduced DCAD had little effect on sow and litter response variables. However, ADFI during lactation and overall was linearly increased as DCAD decreased in the diet. Yen et al. (1981) fed finishing pigs $4 \% \mathrm{CaCl}_{2}$, which decreased ADFI. Our results indicate a linear $(P<0.001)$ decrease in urine $\mathrm{pH}$ as $D C A D$ is decreased in the diet. Urinary $\mathrm{pH}$ is the response that we used to determine the percentage of SC that would be fed in Exp. 2.

\section{Experiment 2}

Changing DCAD reduced ADFI from d 111 of gestation to d 1 postfarrowing. However, DCAD had no affect on ADFI during lactation and overall. DeRouchey et al. (2003) conducted a pilot study where he fed DCAD of $-200,-100,0,100$, and $200 \mathrm{mEq} / \mathrm{kg}$. The results showed that negative DCAD reduced feed intake, and the lowest DCAD that should be fed to lactating sows was 0 $\mathrm{mEq} / \mathrm{kg}$. After the pilot study, DCAD's of 0, 100, 200, 350, and $500 \mathrm{mEq} / \mathrm{kg}$ were fed. The authors reported that increasing DCAD had no effect on ADFI (DeRouchey et al., 2003). Research in dairy cows and in growing pigs suggests that feeding diets with a negative DCAD decreases feed intake (Escobosa et al., 1984; Patience et al., 1987). DeRouchey et al. (2003) reported that increasing DCAD reduced percent survivability of pigs and number weaned. In our experiment, results indicate that reducing DCAD (45 mEq/kg) tended to improve percent survivability of pigs and number weaned, but the effect was not significant. 
DeRouchey et al. (2003) reported that when DCAD is reduced below a standard C-SBM diet, sow's milk production increases, which may increase percent survivability in pigs. Overall, our results and those reported by DeRouchey et al. (2003) are in agreement. Dove and Haydon et al. (1994) fed sows diets with DCAD levels of $130.8,161.2$, and $250.8 \mathrm{mEq} / \mathrm{kg}$ and reported no differences in feed intake, days to estrus, percent survivability in pigs or litter weight gain regardless of dietary treatments. In our experiment, reducing DCAD significantly increased the number of days to estrus. Our results cannot be compared with those of Dove and Haydon et al. (1994) because they did not decrease acid-base balance below $130 \mathrm{mEq} / \mathrm{kg}$. In our experiment, the highest DCAD was $140 \mathrm{mEq} / \mathrm{kg}$.

Acidifiers are not growth promotants. They are included in the diet for metabolic purposes such as bone metabolism, Ca metabolism, maintaining blood $\mathrm{pH}$, and reducing urinary $\mathrm{pH}$. DeRouchey et al. (2003) reported that increasing DCAD linearly increased urinary $\mathrm{pH}$ and bacterial counts in the urine. Sows with reduced bacterial concentrations had a reduced risk of urinary tract infections. Sows that farrow in areas contaminated with excess fecal matter are at risk for bacterial infections. Bacterial infections may decrease rebreeding performance and litter health. DeRouchey et al. (1998) reported that Ca concentrations in the blood decreased as DCAD increased. This response does not agree with our results. Our data showed that plasma Ca slightly decreased as DCAD decreased, but the effect was not significant. Jackson et al. (1994) reported that plasma Ca is similar among treatments regardless of DCAD or Ca\% in the diet. Tucker et al. (1988) and Waterman et al. (1991) used dairy cows to investigate plasma Ca in response to high and low DCAD diets and found no relationship between the two. These observations agree with our results. 


\section{CHAPTER 4}

\section{SUMMARY AND CONCLUSIONS}

This research was conducted to determine if changing DCAD of a standard C-SBM diet during late gestation and in lactation would have an effect on sow productivity.

Experiment 1 was conducted to determine what percentage of acidifier would be adequate to reduce urinary $\mathrm{pH}$. Reducing DCAD increased the number of stillbirths $(P<0.10)$. Reducing the DCAD linearly decreased urinary $\mathrm{pH}(P<0.001)$.

In Exp. 2, changing DCAD did not affect $(P>0.10)$ sow growth or litter response variables. However, DCAD decreased $(P<0.001)$ urinary $\mathrm{pH}$. Reducing DCAD $(45 \mathrm{mEq} / \mathrm{kg})$ below a standard C-SBM diet (140 mEq/kg) tended to improve sow and litter response variables. Reducing DCAD tended to improve number of pigs weaned $(P=0.18)$, initial litter weight adjusted for mortality $(P=$ $0.13)$, and percent survivability $(P=0.19)$, but these effects were not significant. In our experiment, reducing DCAD during the previous lactation improved some response variables in subsequent farrowings in sows. Sows that had been fed a reduced DCAD $(45 \mathrm{mEq} / \mathrm{kg})$ diet showed an increase in total number of pigs born $(P<0.08)$ and pigs born alive $(P<0.02)$.

In conclusion, decreasing cations and increasing anions can improve sow health and reproductive performance. These experiments showed that reducing DCAD reduced urine $\mathrm{pH}$ and some sow and litter performance variables were improved when compared to the other dietary treatments. Long term studies need to be conducted to determine if reducing DCAD throughout gestation would increase sow productivity. 


\section{REFERENCES}

Austic, R. E., R. D. Boyd, K. C. Klasing, and W. W. Riley, Jr. 1983. Effect of dietary electrolyte balance on growth performance in swine. J. Anim. Sci. 57(Suppl. 1):236. (Abstr.)

Block, E., and LeClerc, H. 1989. Effects of reducing dietary cation-anion balance for prepartum dairy cows with specific reference to hypocalcemic parturient paresis. Can. J. Anim. Sci. 69:411-423.

Block, E. 1984. Manipulating dietary anions and cations for prepartum dairy cows to reduce incidence of milk fever. J. Dairy Sci. 67:2939-2948.

DeRouchey, J. M., J. D. Hancock, R. H. Hines, H. Coa, D. J. Lee, C. A. Maloney, and J. S. Parks. 1998. Effects of inorganic and organic acids on urine pH in lactating sows. Pages 21-24 in Swine Day 1998, Kansas State University.

DeRouchey, J. M., J. D. Hancock, R. H. Hines, K. R. Cummings, D. J. Lee, C. A. Maloney, D. W. Dean, J. S. Parks, and H. Cao. 2003. Effects of dietary electrolyte balance on the chemistry of blood and urine in lactating sows and sow litter performance. J. Anim. Sci. 81:3067-3074.

Dove, C. R., and K. D. Haydon. 1994. The effect of various diet nutrient densities and electrolyte balances on sow and litter performance during two seasons of the year. J. Anim. Sci. 72:1101-1106.

Escobosa, A., C. E. Coppock, L. D. Rowe, Jr., W. L. Jenkins, and C. E. Gates. 1984. Effects of dietary sodium bicarbonate and calcium chloride on physiological responses of lactating dairy cows in hot weather. J. Dairy Sci. 67:574.

Giesy, J. G., W. K. Sanchez, M. A. McGuire, J. J. Higgins, L. A. Griffel, and M. A. Guy. 1997. Quantifying the relationship of dietary cation-anion difference to blood calcium in cows during hypocalcemia. J. Dairy Sci. 80(Suppl. 1):142.

Goff, J. P., and R. L. Horst. 1998. Use of hydrochloric acid as a source of anions for prevention of milk fever. J. Dairy Sci. 81:2874-2880.

Horst, R. L., J. P. Goff, T. A. Reinhardt, and D. R. Buxton. 1997. Strategies for preventing milk fever in dairy cattle. J. Dairy Sci. 80:1269-1280.

Jackson, J. A., and R. W. Hemken. 1994. Calcium and cation-anion balance effects on feed intake, body weight gain, and humoral response of dairy calves. J. Dairy Sci. 77:1430-1436.

Jardon, P., DVM. The use of SoyChlor to balance rations for dietary cation-anion difference (DCAD). Available: http://www.soychlor.com/\%5CTECHNICAL\%5C172400902.PDF. Accessed Aug. 21, 2005.

Jordan, E. R., and Fourdraine R. 1993. Characterization of the management practices of the top DHI milk producing herds in the country. J. Dairy Sci. 76:3247.

NRC. 1998. Pages 3-6, 98, and 118-121 in Nutrient Requirements of Swine. $10^{\text {th }}$ rev. ed. Natl. Acad. Press, Washington, DC. 
NRC. 2001. Pages 105-107 and 184-185 in Nutrient Requirements of Dairy Cattle. $7^{\text {th }}$ rev.ed. Natl. Acad. Press, Washington, DC.

Oetzel, G. R., M. J. Fettman, D. W. Hamar, and J. D. Olson. 1991. Screening of anionic salts for palatability, effects on acid-base status, and urinary calcium excretion in dairy cows. J. Dairy Sci. 74:965-971.

Patience, J. F., R. E. Austic, and R. D. Boyd. 1987. Effect of dietary electrolyte balance on growth and acid-base status in swine. J. Anim. Sci. 64:457-466.

Purina Mills Dairy News. 2000. Feeding cows to prevent milk fever- art or science?. Available: http://dairy.purinamills.com/12 00.html. Accessed Sept. 20, 2005.

Riond, Jean-Luc. 2001. Animal nutrition and acid-base balance. Eur. J. Nutr. 40:245-254.

Steel, R. G. D., and J. H. Torrie. 1980. Principles and Procedures of Statistics: A Biometrical Approach. 2nd ed. McGraw-Hill Book Co., New York.

Tucker, W. B., G. A. Harrison, and R. W. Hemken. 1988. Influence of dietary cation-anion balance on milk, blood, urine and rumen fluid in lactation dairy cows. J. Dairy Sci. 71:346.

Tucker, W. B., Z. Xin, and W. Hemken. 1991. Influence of calcium chloride on systemic acid- base status and calcium metabolism in dairy heifers. J. Dairy Sci. 74:1401-1407.

USDA. 2003. 2003 Agricultural Statistics. Available: http://www.usda.gov/nass/pubs/agr03/03 ch7.pdf. Accessed: Oct. 10, 2005.

Waterman, D. F., T. S. Swenson, W. B. Tucker, and R. W. Hemken. 1991. Role of magnesium in the dietary cation-anion balance equation for ruminants. J. Dairy Sci. 74:1866-1873.

West Central Soy. The new generation of anions. Available: http://www.soychlor.com/faqs.asp. Accessed Sept. 12, 2005.

Yen, J. T., G. Pond, and R. L. Prior. 1981. Calcium chloride as a regulator of feed intake and weight gain in pigs. J. Anim. Sci. 52:778-782. 


\section{APPENDIX A}

List of Abbreviations

Item

Abbreviation

Adjusted for mortality

After cross-fostering

Corn

Dietary Cation-Anion Difference

Metabolizable Energy

Soybean meal

SoyChlor

AM
ACF
C
DCAD
ME
SBM
SC

AM

$\mathrm{C}$

$M E$

$\mathrm{SC}$ 


\section{APPENDIX B}

Equations Used in Diet Formulations

Equations for use in estimating energy from chemical analysis of a feedstuff (NRC, 1998)

$$
\begin{aligned}
& \mathrm{GE}=4,143+(56 \times \% \mathrm{EE})+(15 \times \% \mathrm{CP})-(44 \times \% \text { Ash }) \\
& \mathrm{DE}=949+(0.789 \times \mathrm{GE})-(43 \times \% \mathrm{Ash})-(41 \times \% \mathrm{NDF})
\end{aligned}
$$

With the following correction for increased body weight:

$$
\begin{aligned}
& \mathrm{DE}=1,391+(0.58 \times \mathrm{DE})+(23 \times \% \mathrm{EE})+(12.7 \times \% \mathrm{CP}) \\
& \mathrm{ME}=\mathrm{DE} \times(1.003-(0.0021 \times \% \mathrm{CP}))
\end{aligned}
$$

DCAD Equation (Philip Jardon, DVM, MS):

$$
(\mathrm{Na}+\mathrm{K}+.15 \mathrm{Ca}+.15 \mathrm{Mg})-(\mathrm{Cl}+.20 \mathrm{~S}+.30 \mathrm{P})=\mathrm{DCAD} \text { in } \mathrm{mEq} / \mathrm{kg} \mathrm{DM}
$$




\section{APPENDIX C}

Analysis of SoyChlor (SC)

\begin{tabular}{lc}
\hline & Item \\
\hline & $\%$ \\
Crude protein & 22.10 \\
Crude fat & 6.81 \\
Crude fiber & 4.90 \\
Ash & 16.14 \\
Moisture & 10.77 \\
NDF & 18.47 \\
Taurine & 0.04 \\
Hydroxyproline & 0.08 \\
Aspartic acid & 1.52 \\
Threonine & 0.84 \\
Serine & 0.99 \\
Glutamic acid & 3.50 \\
Proline & 1.65 \\
Lanthionine & 0.01 \\
Glycine & 0.83 \\
Alanine & 1.51 \\
Cysteine & 0.39 \\
Valine & 1.12 \\
Methionine & 0.34 \\
Isoleucine & 0.85 \\
Leucine & 2.43 \\
Tyrosine & 0.80 \\
Phenylalanine & 1.07 \\
Hydroxylysine & 0.00 \\
Histidine & 0.58 \\
Ornithine & 0.02 \\
Lysine & 0.77 \\
Arginine & 0.98 \\
Tryptophan & 0.10 \\
Ca & 3.40 \\
Mg & 2.73 \\
P & 0.41 \\
K & 0.56 \\
Na & 0.11 \\
S & 0.61 \\
Cl & 9.49 \\
\hline
\end{tabular}


VITA

Melanie L. Roux was born April 22, 1980, in New Orleans, Louisiana. Melanie grew up in New Orleans until the age of 15 , and then she moved to Ponchatoula, Louisiana. She graduated from Ponchatoula High School in May 1998. Melanie began her undergraduate career at Louisiana State University where she earned a Bachelor's Degree in Animal Science in December 2002. In August of 2003, Melanie returned to Louisiana State University in pursuit of a master of science degree in non ruminant nutrition. Currently, Melanie is a candidate for her master's degree in animal sciences- non-ruminant nutrition. 